\title{
Review Article: \\ Prognostic Value of CK5/6 Expression in Urinary Bladder Carcinoma
}

\author{
GEHAD R.A. EL-GAPHRAWY, M.Sc.; MARWA M. SERAG EL-DIEN, M.D.; \\ SHEREEN F. MAHMOUD, M.D. and ASMAA G. ABDOU, M.D.
}

The Department of Pathology, Faculty of Medicine, Menoufia University

\begin{abstract}
Background: Bladder cancer in Egypt is the most prevalent malignancy among Egyptian males (16\%), producing $>7900$ deaths annually, which is strikingly higher than most other parts of the world. The genesis and progression of urothelial bladder carcinoma (UBC) is known to involve alterations in several molecular pathways. Subtyping of bladder carcinoma patients based on the molecular alterations in their primary tumors may permit risk stratification and administration of more personalized therapies.
\end{abstract}

Aim of Study: The aim of this study is to review the studies investigating the frequency of CK 5/6 expression and its value in the stratification of urothelial bladder carcinoma in English literature.

Material and Methods: The data were retrieved from databases (PubMed, Medscape and Google scholar) and also material available on the Internet from 2001 till 2019. A structured systematic review was performed with the results tabulated.

Results: The initial search presented 8 articles (20012019). The frequency of CK $5 / 6$ expression in UBC cases ranged between $19.7 \%$ and $62 \%$. Positivity of CK $5 / 6$ showed significant association with female gender, advanced tumor stage and pure SCC and UC with squamous differentiation. Positivity for CK 5/6 showed significant association with shorter overall survival in UC cases with squamous differentiation. CK5/6 expression alone was not associated with clinical outcome in any of the articles but showed significant association when combined with other markers.

Conclusions: CK 5/6 as a basal marker could identify aggressive subtypes of urothelial carcinoma as those associated with squamous differentiation and advanced stage, however, it is not related to grading.

Key Words: CK 5/6-Immunohistochemistry-Molecular classification - Basal - Luminal - Urothelial carcinoma - Urinary bladder cancer.

Correspondence to: Dr. Gehad R.A. El-Gaphrawy, The Department of Pathology, Faculty of Medicine, Menoufia University

\section{Introduction}

URINARY bladder cancer (UBC) is a global and national health problem, being an important cause of morbidity and mortality. It ranks the ninth in the worldwide cancer incidence [1]. In Egypt, the relative frequency of urinary bladder cancer is $18.3 \%$ [2] . The highest mortality rate worldwide (16.3 per 100.000) occurs in Egyptian males, which is twice as high as the highest rates in Europe and over 4 times higher than that in the United States [3].

The genesis and progression of UBC is now known to involve alterations in several molecular pathways. These alterations often dictate the rate of tumor progression, and may therefore act as surrogates for identifying patients who have more aggressive disease. Subtyping patient populations based on the molecular alterations in their primary tumors may therefore permit risk stratification and administration of more personalized therapies [4]

Cytokeratin 5/6 (CK 5/6) is an intermediatesized basic keratin. In normal tissue, CK5/6 is mainly expressed in keratinizing (epidermis) and non-keratinizing (mucosa) squamous epithelium. It is also expressed in basal-myoepithelial cell layer of the prostate, breast, and salivary glands. CK5/6 is also seen in benign and malignant tumors of epidermal, squamous mucosal, and myoepithelial origins [5].

The CK 5/6 staining pattern and intensity varied between well differentiated and poorly differentiated transitional cell carcinoma. In low-grade papillary transitional cell carcinoma (TCC), the CK 5/6- positive cells were observed at the basal layers of the papillae; whereas in high-grade TCC, tumor cells were diffusely positive for CK 5/6 in some cases [6]. 


\section{Aim of the study:}

The aim of this study is to review the studies investigating the frequency of CK 5/6 expression and its value in the stratification of urothelial bladder carcinoma in English literature.

\section{Material and Methods}

\section{Search strategy:}

PubMed, Medscape and Google scholar were used as Medline databases together with material available on the Internet in the period between 2001 and 2019. We used CK 5/6, immunohistochemical, molecular classification, basal, luminal, urothelial carcinoma, urinary bladder cancer as searching terms.

\section{Study selection:}

We assessed all the studies independently for inclusion criteria that must be fulfilled and were:

1- Published in the English language.

2- Published in peer-reviewed journals.

3- Focused on CK 5/6 and urothelial bladder carcinoma.

4- Done on histological specimens of urothelial bladder carcinoma.

We exclude the studies that did not fulfill the above criteria such as:

1- CK 5/6 in urothelial carcinoma of any origin other than urinary bladder as renal pelvis and prostate.

2- CK 5/6 in carcinomas other than those of urothelial origin.

\section{Data extraction:}

Data from each eligible study were independently abstracted in duplicate using a data collection form to capture information on study characteristics, interventions, quantitative results reported for each outcome of interest. Conclusions and comments on each study were made.

Due to small number of the studied articles and heterogeneity in the collected data, it was not possible to perform meta-analysis. Significant data were collected. Thus, a structured review was performed with the result tabulated.

The analyzed publications were evaluated according to evidence-based medicine (EBM) criteria using the classification of the U.S. Preventive Services Task Force \& UK National Health Service protocol for EBM in addition to the Evidence Pyramid.

\section{U.S. Preventive services task force:}

- Level I: Evidence obtained from at least one properly designed randomized controlled trial.

- Level II-1: Evidence obtained from well-designed controlled trials without randomization.

- Level II-2: Evidence obtained from well-designed cohort or case-control analytic studies, preferably from more than one center or research group.

- Level II-3: Evidence obtained from multiple time series with or without the intervention. Dramatic results in uncontrolled trials might also be regarded as this type of evidence.

- Level III: Opinions of respected authorities, based on clinical experience, descriptive studies, or reports of expert committees.

\section{Quality assessment:}

The quality of all the studies was assessed. Important factors included, study design, attainment of ethical approval, evidence of a power calculation, specified eligibility criteria, appropriate controls, adequate information, and specified assessment measures.

\section{Data synthesis:}

A structured systematic review was performed with the results tabulated.

\section{Results}

\section{Study selection and characteristics:}

Eight potentially relevant publications were and included in the review as they fulfilled the inclusion criteria. The included eight articles were human, retrospective or cohort studies using immunohistochemical staining on formalin fixed paraffin embedded blocks of bladder carcinoma cases. The data extracted from the 8 articles were presented in Table (1).

The age of the studied cases ranged between 31 and 89 years with a male to female ratio as 2.16:1 (lowest ratio) and 39.3:1 (highest ratio).

CK 5/6 expression in urothelial bladder carcinoma cases ranged between $19.7 \%$ and $62 \%$ that showed significant association with female gender in one study [7].

Positive CK 5/6 in urothelial carcinoma cases showed association with advanced tumor stage in two studies [7,8]

Regarding grade of tumor, CK5/6 was associated with low-grade urothelial carcinoma in one 
study [8] and with high tumor grade in another study [7]

As regarding histopathologic type, CK 5/6 was expressed in pure SCC and UC with squamous differentiation in one study [9].
CK 5/6 positivity showed significant shorter overall survival in UC cases with squamous differentiation in one study [10]. On the other hand, CK5/6 expression alone was not associated with clinical outcome in any of the reviewed articles.

Table (1): Frequency of CK 5/6 expression and relation to available cilinicopathological data.

\begin{tabular}{|c|c|c|c|c|c|c|c|}
\hline \multirow[b]{2}{*}{ Reference } & \multirow[b]{2}{*}{$\begin{array}{l}\text { Type of } \\
\text { study \& } \\
\text { number } \\
\text { of cases }\end{array}$} & \multirow[b]{2}{*}{$\begin{array}{l}\text { Age (years) } \\
\text { Mean } \pm \text { SD } \\
\text { Range }\end{array}$} & \multirow[b]{2}{*}{$\begin{array}{l}\text { Gender } \\
\text { M:F }\end{array}$} & \multicolumn{4}{|c|}{ CK 5/6 positivity \& relation to clinicopathological data } \\
\hline & & & & $\begin{array}{l}\text { Positive } \\
\text { cases (\%) }\end{array}$ & $\begin{array}{l}\text { Histopathological } \\
\text { features } \\
\text { (stage, grade, } \\
\text { histoogica type) }\end{array}$ & $\begin{array}{l}\text { Overall } \\
\text { survival }\end{array}$ & $\begin{array}{l}\text { Patient outcome } \\
\text { (Univariate \& } \\
\text { multivariate } \\
\text { analysis) }\end{array}$ \\
\hline (Jangir et al., 2019) & $\begin{array}{l}\text { Retrospective } \\
40 \text { MIBC }\end{array}$ & $\begin{array}{l}56.6 \pm 9.62 \\
31-76 \text { years }\end{array}$ & $12.3: 1$ & $\begin{array}{l}23 / 40 \\
(57.5 \%)\end{array}$ & $\begin{array}{l}\text { No significant } \\
\text { association }\end{array}$ & $\begin{array}{l}\text { Shorter in UC } \\
\text { cases with } \\
\text { squamous } \\
\text { differentiation } \\
(p=0.0498)\end{array}$ & $\begin{array}{l}\text { No significant } \\
\text { correlation } \\
\text { with survival }\end{array}$ \\
\hline (Calvete et al., 2019) & $\begin{array}{l}\text { Retrospective } \\
121 \text { NMIBC \& } \\
\text { MIBC }\end{array}$ & $\begin{array}{l}68.1 \pm 9.25 \\
44-89 \text { years }\end{array}$ & 39.3:1 & $\begin{array}{l}48 / 121 \\
(39.7 \%)\end{array}$ & $\begin{array}{l}\text { No significant } \\
\text { association }\end{array}$ & $\begin{array}{l}\text { No significant } \\
\text { association }\end{array}$ & $\begin{array}{l}\text { CK5/62 } \\
\text { expression } \\
\text { alone was not } \\
\text { associated } \\
\text { with clinical } \\
\text { outcome. }\end{array}$ \\
\hline (Wang et al., 2019) & $\begin{array}{l}\text { Cohort } \\
2010-2016 \\
91 \mathrm{MIBC}\end{array}$ & $\begin{array}{l}\text { Not available } \\
39-89 \text { years }\end{array}$ & $2.37: 1$ & $\begin{array}{l}52 / 91 \\
(57.1 \%)\end{array}$ & $\begin{array}{l}\text { No significant } \\
\text { association }\end{array}$ & $\begin{array}{l}\text { No prognostic } \\
\text { significance }\end{array}$ & $\begin{array}{l}\text { CK5/6 alone } \\
\text { was not } \\
\text { prognostically } \\
\text { significant }\end{array}$ \\
\hline $\begin{array}{l}\text { (Rodriguez Pena et al., } \\
\text { 2019) }\end{array}$ & $\begin{array}{l}193 \text { TURBTs } \\
\text { taken from } 60 \\
\text { patients } \\
\text { (NMIBC \& } \\
\text { MIBC) }\end{array}$ & $\begin{array}{l}68 \\
\text { (No available } \\
\text { SD) } \\
47-89 \text { years }\end{array}$ & $2.16: 1$ & $\begin{array}{l}\text { Under } 50 \% \\
\text { positivity } \\
\text { (number of } \\
\text { positive cases } \\
\text { not mentioned) }\end{array}$ & $\begin{array}{l}\text { Significant } \\
\text { association with } \\
\text { advanced stage } \\
(p=0.04) \text { and } \\
\text { low-grade } \\
\text { urothelial } \\
\text { carcinoma } \\
(p=0.01)\end{array}$ & $\begin{array}{l}\text { No significant } \\
\text { association }\end{array}$ & $\begin{array}{l}\text { No significant } \\
\text { association }\end{array}$ \\
\hline (Hashmi et al., 2018) & $\begin{array}{l}127 \text { NMIBC \& } \\
\text { MIBC (240 } \\
\text { specimens) }\end{array}$ & $63.23 \pm 13.9$ & $3: 1$ & 25/127 (19.7\%) & $\begin{array}{l}\text { Significant } \\
\text { association with } \\
\text { advanced tumor } \\
\text { stage } \\
(p=0.049), \text { high } \\
\text { tumor grade } \\
(p=0.000) \text { and } \\
\text { with female } \\
\text { gender } \\
(p=0.014) .\end{array}$ & $\begin{array}{l}\text { No significant } \\
\text { association }\end{array}$ & $\begin{array}{l}\text { No significant } \\
\text { association }\end{array}$ \\
\hline (Kaufmann et al., 2001) & $\begin{array}{l}20 \text { metastatic } \\
\text { urothelial } \\
\text { carcinoma } \\
\text { cases }\end{array}$ & No available & data & $\begin{array}{l}7 / 20 \\
(35 \%)\end{array}$ & $\begin{array}{l}\text { No significant } \\
\text { association }\end{array}$ & No avai & able data \\
\hline (Chu and Weiss, 2002) & $24 \mathrm{TCC}$ & No available & data & $\begin{array}{l}15 / 24 \\
(62 \%)\end{array}$ & $\begin{array}{l}\text { No significant } \\
\text { association }\end{array}$ & No avai & able data \\
\hline (Gaisa et al., 2011) & $\begin{array}{l}89 \text { pure SCCs } \\
\text { and mixed } \\
\text { UC/SCCs, } 66 \\
\text { urothelial } \\
\text { carcinomas }\end{array}$ & No available & data & $\begin{array}{l}\text { 22/66 }(30.2 \%) \text { of } \\
\text { UC cases, } \\
76.6 \% \text { of SCC } \\
\text { cases }\end{array}$ & $\begin{array}{l}\text { Significant } \\
\text { association with } \\
\text { pure SCC and } \\
\text { UC with } \\
\text { squamous } \\
\text { differentiation } \\
(p<0.01) \text {. }\end{array}$ & No avai & able data \\
\hline $\begin{array}{l}\text { UC : Urothelial carcin } \\
\text { SCCs : Squamous cell } \\
\text { SD : Standard deviati }\end{array}$ & $\begin{array}{l}\text { oma. } \\
\text { arcinomas. } \\
\text { on. }\end{array}$ & $\begin{array}{l}\text { MIB } \\
\text { TCC } \\
\text { NMI }\end{array}$ & $\begin{aligned}: & \mathrm{Mu} \\
& : \mathrm{Tr} \\
\mathrm{C} & : \mathrm{No}\end{aligned}$ & $\begin{array}{l}\text { le invasive bladde } \\
\text { itional cell carcinc } \\
\text { muscle invasive bl }\end{array}$ & $\begin{array}{l}\text { r carcinoma. } \\
\text { ma. } \\
\text { ladder carcinoma. }\end{array}$ & & \\
\hline
\end{tabular}

\section{Discussion}

Histopathologic features of bladder cancer are important items for therapeutic decisions, but identification of UC molecular subtypes has the potential to guide patient stratification for progno- sis, treatment and administration of more personalized therapies [11,12].

Molecular classification of bladder cancer based on whole genome expression profiling was done by several groups that classify urothelial carcinoma 
into different classes that showed striking similarities to the intrinsic basal and luminal subtypes identified in human breast cancers [13-16]

In a meta-analysis done using whole transcriptome expression data from four independent cohorts for clustering of basal and luminal biomarkers of bladder carcinoma, they found that a subset of tumor displayed strong expression of high molecular weight cytokeratins (that characterize basal urothelial layer) including CK 5/6 and was referred to as basal subtype of bladder carcinoma [17].

Even prior to molecular profiling studies, it has been noted that MIBCs that express basal cytokeratins including CK5/6 were associated with poor outcomes $[\mathbf{9 , 1 8}]$.

In the current review, the age of studied cases were available in 5 articles that ranged between 31 and 89 years. Bladder cancer can occur at any age, but it is generally a disease of middle-aged and elderly people $[\mathbf{1 9 , 2 0 ]}$. Bladder TCC in young people is rare and $<1 \%$ of cases develop in the first 4 decades of life [21]. The incidence of bladder cancer increases dramatically with age. Rates in patients aged $>70$ years are about 2-3 times higher than those between 55-69 years, and 15 to 20 times higher than those between 30-50 years [19].

In the present review, five articles demonstrated the ratio between male and female gender that was almost near to each other and showed higher rate of bladder carcinoma in male than female but only one study showed significant association of CK $5 / 6$ positivity with female gender $(p=0.014)$ [7] This finding can be explained by impact of gender on urinary bladder carcinoma (UBC) incidence as women have a lower UBC incidence up to fourfold [22] and a higher mortality rate than men. The lower UBC incidence is likely to represent historically lower smoking prevalence and less occupational exposure to carcinogens in women. However; the reasons for the higher mortality rate are unclear.

Although UC incidence in female is lower than that in male, it's reported to be with poor prognosis due to underlying histopathological features of presence of squamous differentiation [10]. The latter study demonstrated that all cases with female gender showed squamous differentiation.

In the current review, CK 5/6 expression ranged between $19.7 \%$ [7] and 62\% [6], the frequency of expression depends on the histopathological type of the studied cases as it was the lowest in the study by Hashmi et al., since they investigated only pure urothelial carcinoma cases excluding cases with squamous differentiation and pure SCC. The highest expression (62\%) reported by Chu and Weiss who mentioned that the studied cases were TCC but no comment on presence or absence of divergent differentiation. According to Jangir et al., 2019, CK 5/6 was expressed in 57.5\% of cases, they investigated both pure UC cases and urothelial carcinoma cases with squamous differentiation and showed that CK 5/6 positivity was related to all cases of UC with squamous differentiation.

As regards stage of urothelial carcinoma, CK $5 / 6$ positivity was related to tumor stage IV according to Jangir et al., 2019, infiltration deep into muscularis propria or beyond according to Calvete et al., 2019, association with metastatic tumor at presentation according to Kaufmann et al., 2001. Furthermore, it showed significant statistical association with advanced tumor stage in two studies $(p=0.04 \& p=0.049)[7,8]$

The association with advanced stage is most probably due to the expression of Ck5/6 in "Basallike" subgroup [23]. The basal group showed more EGFR gains or amplifications and TP53 mutations and the degree of p53 expression (reflecting chromosome $17 p$ abnormalities) was significantly associated with pathologic tumor stage, lymphovascular invasion, lymph node metastases, pathologic tumor grade, disease recurrence, and bladder cancer-specific death [24]. Also according to The university of north Carolina classification (UNC), the basal group that were characterized by expression of CK 5/6 contained a claudin-low subgroup, as defined in breast cancer, that was enriched in epithelial-mesenchymal transition (EMT) [16] and so increased expression of genes related to epithelial to mesenchymal transition $[\mathbf{1 1 , 2 5 ]}$

In the current review, only two articles showed significant association between CK 5/6 positivity and tumor grade but both results were opposite to each other. One study showed significant association with high tumor grade [7] and the other study showed significant association with low tumor grade [8] without explanation. It can be explained by CK 5/6 staining pattern and intensity varied between well differentiated and poorly differentiated transitional cell carcinoma as positivity in basal layer of papillae was observed in low-grade papillary TCC compared to diffuse positivity in some cases of high-grade TCC [6]. It was also found that CK 5/6 expression is associated with high grade invasive duct carcinoma of the breast [26] and with high grade serous ovarian carcinoma [27]. 
In the current review, 3 articles $[\mathbf{9 , 1 0 , 2 8 ]}$ investigated pure UC and UC with squamous differentiation and showed diffuse CK 5/6 positivity in cases with squamous differentiation according to Wang et al., 2019, related to all urothelial carcinoma cases with squamous differentiation according to Jangir et al., 2019 and showed statistical significance with pure SCC and UC with squamous differentiation $(p<0.01)$ according to Gaisa et al., 2011. This can be explained by CK $5 / 6$ is considered to be marker of basal and squamous cell differentiation in several normal epithelia and human tumors [29]. FOXA1 expression is reduced in areas of squamous differentiation due to epigenetic modification of the FOXA1 promoter in the form of DNA methylation [30,31] and FOXA1 is associated with the basal-squamous molecular subtype [32]. This phenotypic plasticity may reflect a natural disease process in which progression of some bladder tumors is associated with luminal to basal subtype switching [11,15]. Another possibility is that the observed gain of basal marker expression may recapitulate the early pre-microscopic stages of tumor differentiation toward a squamous phenotype which expresses basal markers [30].

In the present review, CK 5/6 positivity showed significant shorter overall survival in UC cases with squamous differentiation $(p=0.0498)$. This can be explained by aggressive behavior of UC cases with squamous differentiation [33-36]. UC cases with squamous differentiation are associated with poor prognosis and outcome as they are more likely to present with extravesical disease and less likely to have organ-confined disease than those with pure urothelial carcinoma and was associated with a high tumor stage and a high rate of pelvic nodal metastasis [36]. Prior studies have reported that urothelial carcinoma with squamous differentiation is more aggressive because of its resistance to radiotherapy, chemotherapy, and immunotherapy [33-35].

In the current review, CK5/6 expression alone was not associated with clinical outcome in any of the reviewed articles, however, simultaneous expression with other markers such as FAP (Fibroblast activation protein) and CD44 expression predict worse cancer-specific survival $(\mathrm{HR}=2.304$; $p=0.001$ ) according to Calvete et al., 2019.

Conclusions: CK 5/6 as a basal marker could identify aggressive subtypes of urothelial carcinoma as those associated with squamous differentiation and advanced stage, however, it is not related to grading.

\section{References}

1- MOKHTAR N., SALAMA A., BADAWY O., KHORSHED E., MOHAMED G., IBRAHIM M. and ABDELAZIM H.: Cancer Pathology Registry 2000-2011, Cairo, Egypt, Cairo University, 2016.

2- EL-BOLKAINY M., NOUH M. and EL-BOLKAINY G.: "Epidemiology of cancer," in Pathology of Cancer, Cairo Press, Cairo, Egypt, Chapter 2: 15-31, 2013.

3- IBRAHIM A., HUSSEIN H., ISMAIL K., HABLAS A., ABDEL BAR I. and RAMADAN M.: Cancer profile in Gharbiah Egypt, methodology and results. 1999, Cairo, Egypt, Gharbiah Population-Based Cancer Registry (GPCR), 2002.

4- MITRA A.P.: Molecular substratification of bladder cancer: moving towards individualized patient management. Therapeutic Advances in Urology, 8: 215-233, 2016.

5- COOPER D., SCHERMER A. and SUN T.T.: Classification of human epithelia and their neoplasms using monoclonal antibodies to keratins: Strategies, applications, and limitations. Lab. Invest, 52: 243-256, 1985.

6- CHU P.G. and WEISS L.M.: Expression of cytokeratin 5/6 in epithelial neoplasms: An immunohistochemical study of 509 cases. Mod. Pathol., 15: 6-10, 2002.

7- HASHMI A.A., HUSSAIN Z.F., IRFAN M., EDHI M.M., KANWAL S., FARIDI N. and KHAN A.: Cytokeratin 5/6 expression in bladder cancer: Association with clinicopathologic parameters and prognosis. BMC Res. Notes, 11: 207-211, 2018.

8- RODRIGUEZ PENA M.D.C., CHAUX A., EICH M.L. TREGNAGO A.C., TAHERI D., BORHAN W., SHARMA R., REZAEI M.K. and NETTO G.J.: Immunohistochemical assessment of basal and luminal markers in nonmuscle invasive urothelial carcinoma of bladder. Virchows Arch., 475: 349-356, 2019.

9- GAISA N.T., BRAUNSCHWEIG T., REIMER N., BORNEMANN J., ELTZE E., SIEGERT S., TOMA M., VILLA L., HARTMANN A. and KNUECHEL R.: Different immunohistochemical and ultrastructural phenotypes of squamous differentiation in bladder cancer. Virchows Arch., 458: 301-312, 2011.

10- JANGIR H., NAMBIRAJAN A., SETH A., SAHOO R.K., DINDA A.K., NAYAK B. and KAUSHAL S.: Prognostic stratification of muscle invasive urothelial carcinomas using limited immunohistochemical panel of Gata3 and cytokeratins 5/6, 14 and 20. Annals of Diagnostic Pathology, 43: 151397-151404, 2019.

11- CHOI W., PORTEN S., KIM S., WILLIS D., PLIMACK E.R., HOFFMAN-CENSITS J., ROTH B., CHENG T., TRAN M., LEE I.L., MELQUIST J., BONDARUK J., MAJEWSKI T., ZHANG S., PRETZSCH S., BAGGERLY K., SIEFKER-RADTKE A., CZERNIAK B., DINNEY C.P. and MCCONKEY D.J.: Identification of distinct basal and luminal subtypes of muscle-invasive bladder cancer with different sensitivities to frontline chemotherapy. Cancer Cell, 25: 152-165, 2014b.

12- SEILER R., ASHAB H.A.D., ERHO N., VAN RHIJN B.W.G., WINTERS B., DOUGLAS J., VAN KESSEL K.E., FRANSEN VAN DE PUTTE E.E., SOMMERLAD M., WANG N.Q., CHOEURNG V., GIBB E.A., PALMERARONSTEN B., LAM L.L., BUERKI C., DAVICIONI 
E., SJÖDAHL G., KARDOS J., HOADLEY K.A., LERNER S.P., MCCONKEY D.J., CHOI W., KIM W.Y., KISS B., THALMANN G.N., TODENHÖFER T., CRABB S.J., NORTH S., ZWARTHOFF E.C., BOORMANS J.L., WRIGHT J., DALL'ERA M., VAN DER HEIJDEN M.S and BLACK P.C.: Impact of Molecular Subtypes in Muscle-invasive Bladder Cancer on Predicting Response and Survival after Neoadjuvant Chemotherapy. European Urology, 72: 544-554, 2017.

13- LINDGREN D., FRIGYESI A., GUDJONSSON S., SJÖDAHL G., HALLDEN C., CHEBIL G., VEERLA S., RYDEN T., MANSSON W., LIEDBERG F. and HÖGLUND M.: Combined Gene Expression and Genomic Profiling Define Two Intrinsic Molecular Subtypes of Urothelial Carcinoma and Gene Signatures for Molecular Grading and Outcome. Cancer Research, 70: 3463-3472, 2010.

14- SJÖDAHL G., LAUSS M., LOVGREN K., CHEBIL G., GUDJONSSON S., VEERLA S., PATSCHAN O., AINE M., M F.O., RINGNÉR M., MANSSON W., LIEDBERG F., LINDGREN D. and HÖGLUND M.: A Molecular Taxonomy for Urothelial Carcinoma. Clinical Cancer Research, 18: 3377-3386, 2012.

15- CHOI W., CZERNIAK B., OCHOA A., SU X., SIEFKERRADTKE A., DINNEY C. and MCCONKEY D.J.: Intrinsic basal and luminal subtypes of muscle-invasive bladder cancer. Nature Reviews Urology, 11: 400-410, 2014 a.

16- DAMRAUER J.S., HOADLEY K.A., CHISM D.D., FAN C., TIGANELLI C.J., WOBKER S.E., YEH J.J., MILOWSKY M.I., IYER G., PARKER J.S. and KIM W.Y.: Intrinsic subtypes of high-grade bladder cancer reflect the hallmarks of breast cancer biology. Proc. Natl. Acad. Sci. USA, 111: 3110-3115, 2014b.

17- DADHANIA V., ZHANG M., ZHANG L., BONDARUK J., MAJEWSKI T., SIEFKER-RADTKE A., GUO C.C., DINNEY C., COGDELL D.E., ZHANG S., LEE S., LEE J.G., WEINSTEIN J.N., BAGGERLY K., MCCONKEY D. and CZERNIAK B.: Meta-Analysis of the Luminal and Basal Subtypes of Bladder Cancer and the Identification of Signature Immunohistochemical Markers for Clinical Use. EBioMedicine, 12: 105-117, 2016.

18- VOLKMER J.-P., SAHOO D., CHIN R.K., HO P.L., TANG C., KURTOVA A.V., WILLINGHAM S.B., PAZHANISAMY S.K., CONTRERAS-TRUJILLO H., STORM T. A., LOTAN Y., BECK A.H., CHUNG B.I., ALIZADEH A.A., GODOY G., LERNER S.P., VAN DE RIJN M., SHORTLIFFE L.D., WEISSMAN I.L. and CHAN K.S.: Three differentiation states risk-stratify bladder cancer into distinct subtypes. Proceedings of the National Academy of Sciences of the United States of America, 109: 2078-2083, 2012.

19- BEN-ABDALLAH M., ZEHANI S., et al.: 1994-2003 evolution and projections by 2024 . North-Tunisia cancer registry: 1999-2003. Tunisia, 25-31, 2009.

20- CHO K.S., HWANG T.K., KIM B.W., YOON D.K., CHANG S.G., KIM S.J., PARK J.Y., CHEON J., SUNG G.T. and HONG S.J.: Differences in tumor characteristics and prognosis in newly diagnosed Ta, T1 urothelial carcinoma of bladder according to patient age. Urology, 73: 828-832, 832 e1, 2009.

21- YOSSEPOWITCH O. and DALBAGNI G.: Transitional cell carcinoma of the bladder in young adults: Presentation, natural history and outcome. J. Urol., 168: 61-66, 2002.
22- FAJKOVIC H., HALPERN J.A., CHA E.K., BAHADORI A., CHROMECKI T.F., KARAKIEWICZ P.I., BREINL E., MERSEBURGER A.S. and SHARIAT S.F.: Impact of gender on bladder cancer incidence, staging, and prognosis. World Journal of Urology, 29: 457-463, 2011.

23- REBOUISSOU S., BERNARD-PIERROT I., DE REYNIS A., LEPAGE M.-L., KRUCKER C., CHAPEAUBLANC E., HRAULT A., KAMOUN A., CAILLAULT A., LETOUZ E., ELAROUCI N., NEUZILLET Y., DENOUX Y., MOLINI V., VORDOS D., LAPLANCHE A., MAILL P., SOYEUX P., OFUALUKA K., REYAL F., BITON A., SIBONY M., PAOLETTI X., SOUTHGATE J., BENHAMOU S., LEBRET T., ALLORY Y. and RADVANYI F.O.: EGFR as a potential therapeutic target for a subset of muscle-invasive bladder cancers presenting a basallike phenotype. Science Translational Medicine, 6: 244ra91-244ra91, 2014.

24- ABRAMS P. and KHOURY S.: International consultation on urological diseases: Evidence-based medicine overview of the main steps for developing and grading guideline recommendations. Neurourology and Urodynamics, 29: 116-118, 2012.

25- OCHOA A.E., CHOI W., SU X., SIEFKER-RADTKE A., CZERNIAK B., DINNEY C. and MCCONKEY D.J.: Specific micro-RNA expression patterns distinguish the basal and luminal subtypes of muscle-invasive bladder cancer. Oncotarget, 7: 80164-80174, 2016.

26- BHALLA A., MANJARI M., KAHLON S., KUMAR P. and KALRA N.: Cytokeratin 5/6 expression in benign and malignant breast lesions. Indian journal of pathology \& microbiology, 53: 676-680, 2010.

27- TAUBE E.T., DENKERT C., SEHOULI J., UNGER U., KUNZE C.A., BUDCZIES J., DIETEL M., BRAICU E. and DARB-ESFAHANI S.: Cytokeratin 5/6 expression, prognosis, and association with estrogen receptor alpha in high-grade serous ovarian carcinoma. Human Pathology, 67: 30-36, 2017.

28- WANG C.C., TSAI Y.C. and JENG Y.M.: Biological significance of GATA3, cytokeratin 20, cytokeratin 5/6 and 553 expression in muscle-invasive bladder cancer. PloS One, 14: e0221785, 2019.

29- REIS-FILHO J.S., SIMPSON P.T., MARTINS A., PRETO A., GARTNER F. and SCHMITT F.C.: Distribution of p63, cytokeratins 5/6 and cytokeratin 14 in 51 normal and 400 neoplastic human tissue samples using TARP-4 multi-tumor tissue microarray. Virchows Arch., 443: 122132, 2003.

30- DEGRAFF D.J., CLARK P.E., CATES J.M., YAMASHITA H., ROBINSON V.L., YU X., SMOLKIN M.E., CHANG S.S., COOKSON M.S., HERRICK M.K., SHARIAT S.F., STEINBERG G.D., FRIERSON H.F., WU X.-R., THEODORESCU D. and MATUSIK R.J.: Loss of the urothelial differentiation marker FOXA1 is associated with high grade, late stage bladder cancer and increased tumor proliferation. PloS One, 7: e36669-e36669, 2012.

31- WARRICK J.I., SJODAHL G., KAAG M., RAMAN J.D., MERRILL S., SHUMAN L., CHEN G., WALTER V. and DEGRAFF D.J.: Intratumoral Heterogeneity of Bladder Cancer by Molecular Subtypes and Histologic Variants. Eur. Urol., 75: 18-22, 2019.

32- ROBERTSON A.G., KIM J., AL-AHMADIE H., BELLMUNT J., GUO G., CHERNIACK A.D., HINOUE T., 
LAIRD P.W., HOADLEY K.A., AKBANI R., CASTRO M.A.A., GIBB E.A., KANCHI R.S., GORDENIN D.A., SHUKLA S.A., SANCHEZ-VEGA F., HANSEL D.E., CZERNIAK B.A., REUTER V.E., SU X., DE SA CARVALHO B., CHAGAS V.S., MUNGALL K.L., SADEGHI S., PEDAMALLU C.S., LU Y., KLIMCZAK L.J., ZHANG J., CHOO C., OJESINA A.I., BULLMAN S., LERAAS K.M., LICHTENBERG T.M., WU C.J., SCHULTZ N., GETZ G., MEYERSON M., MILLS G.B., MCCONKEY D.J., WEINSTEIN J.N., KWIATKOWSKI D.J. and LERNER S.P.: Comprehensive Molecular Characterization of Muscle-Invasive Bladder Cancer. Cell, 171: 540-556 e25, 2017.

33- LOGOTHETIS C.J., JOHNSON D.E., CHONG C., DEXEUS F.H., OGDEN S., ESCHENBACH A.V. and AYALA A.: Adjuvant Chemotherapy of Bladder Cancer: A Preliminary Report. The Journal of Urology, 139: 1207-1211, 1988.

34- MARTIN J.E., JENKINS B.J., ZUK R.J., BLANDY J.P. and BAITHUN S.I.: Clinical importance of squamous metaplasia in invasive transitional cell carcinoma of the bladder. Journal of Clinical Pathology, 42: 250-253, 1989.
35- GOFRIT O.N., YUTKIN V., SHAPIRO A., PIZOV G., ZORN K.C., HIDAS G., GIELCHINSKY I., DUVDEVANI M., LANDAU E.H. and PODE D.: The Response of Variant Histology Bladder Cancer to Intravesical Immunotherapy Compared to Conventional Cancer. Frontiers in Oncology, 6: 43-47, 2016.

36- LIU Y., BUI M.M. and XU B.: Urothelial Carcinoma With Squamous Differentiation Is Associated With High Tumor Stage and Pelvic Lymph-Node Metastasis. Cancer Control, 24: 78-82, 2017.

37- CALVETE J., LARRINAGA G., ERRARTE P., MARTIN A.M., DOTOR A., ESQUINAS C., NUNES-XAVIER C.E., PULIDO R., LOPEZ J.I. and ANGULO J.C.: The coexpression of fibroblast activation protein (FAP) and basal-type markers (CK 5/6 and CD44) predicts prognosis in high-grade invasive urothelial carcinoma of the bladder. Hum. Pathol., 91: 61-68, 2019.

38- KAUFMANN O., FIETZE E., MENGS J.R. and DIETEL M.: Value of p63 and Cytokeratin 5/6 as Immunohistochemical Markers for the Differential Diagnosis of Poorly Differentiated and Undifferentiated Carcinomas. American Journal of Clinical Pathology, 116: 823-830, 2001.

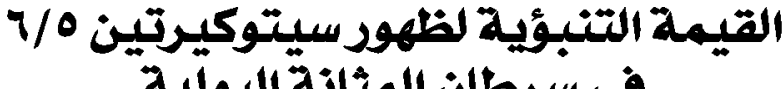 فى سرطان المثانة البولية}

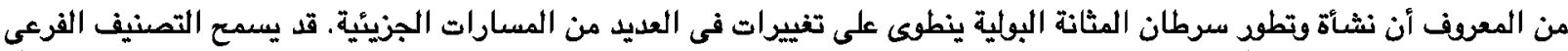

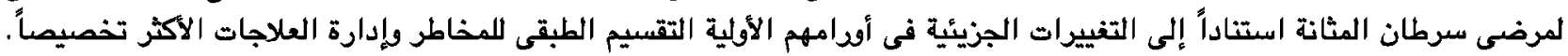

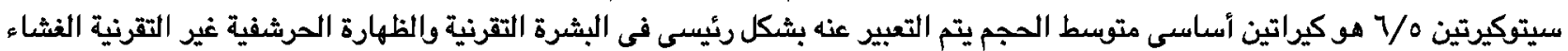

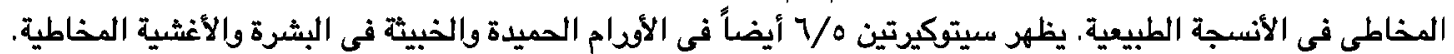

الهدف من هذه الدراسة هو مراجعة الدراسات التى تمقق فى تكرار تعبير سيتوكيرتين Y/0 وقيمتها فى طبقات سرطان المثانة البولية

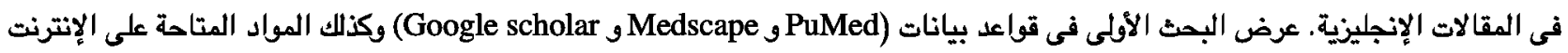

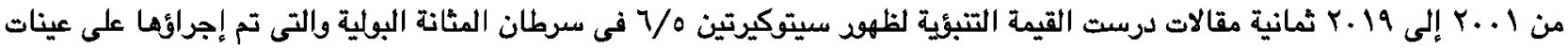

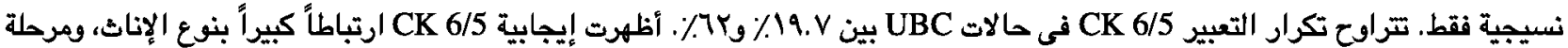

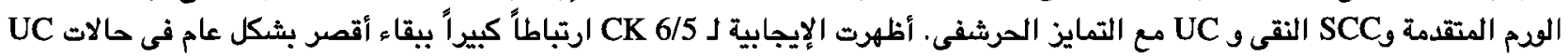

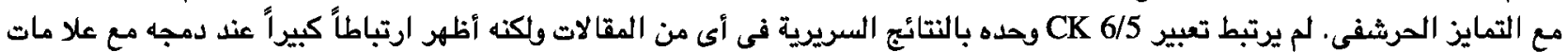

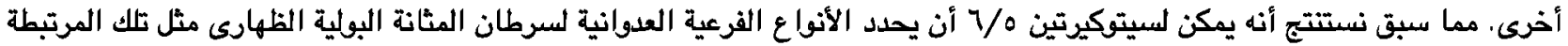

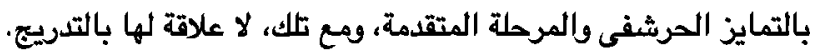

